\title{
Epilogue
}

\section{Sergio, First}

\section{Andrew McLuhan ${ }^{1}$}

DOI: 10.5294/pacla.2020.23.s.8

How to cite this epilogue / Cómo citar este epílogo / Como citar este epílogo McLuhan, A. (2020). Sergio, First. Palabra Clave, 23(supp.), e23s8. https://doi. org/10.5294/pacla.2020.23.s.8

I'm not exactly sure how to write about someone who I knew so little, but who meant so much to me. It's a paradox — and perhaps that's as good a place as any to start to talk about my friend Sergio, who I suspect both enjoyed, and was filled with, paradox.

It's hard for me to say exactly when the last time I saw Sergio was, but I think it was at my father's funeral (Image 1). I remember very much him being there. I remember seeing him with a bandanna partially obscuring his face and thinking that was a bit odd — then finding out that he had a really bad toothache. Man, it must have been awful. Did he already know how sick he was? I don't know.

In this, and many other matters relating to the man, I have more questions than answers, a consequence of the short time I had to get to know him. In that short time, however, Sergio made a great impact. I know his students would have loved him. You only had to meet him once, maybe on the first day of classes, to know this was a special, passionate person.

Very soon after meeting him, mid-May in 2018 in Bogota and environs, I knew this was someone I could get along with. Some dress to impress, some dress to express. Sergio was the latter. You only had to look at him to see that this was someone who didn't mind being a little edgy, someone

1 The McLuhan Institute, Canada. andrew@themcluhaninstitute.com 
Image 1. Eric McLuhan's funeral in Bogota (May 20, 2018).
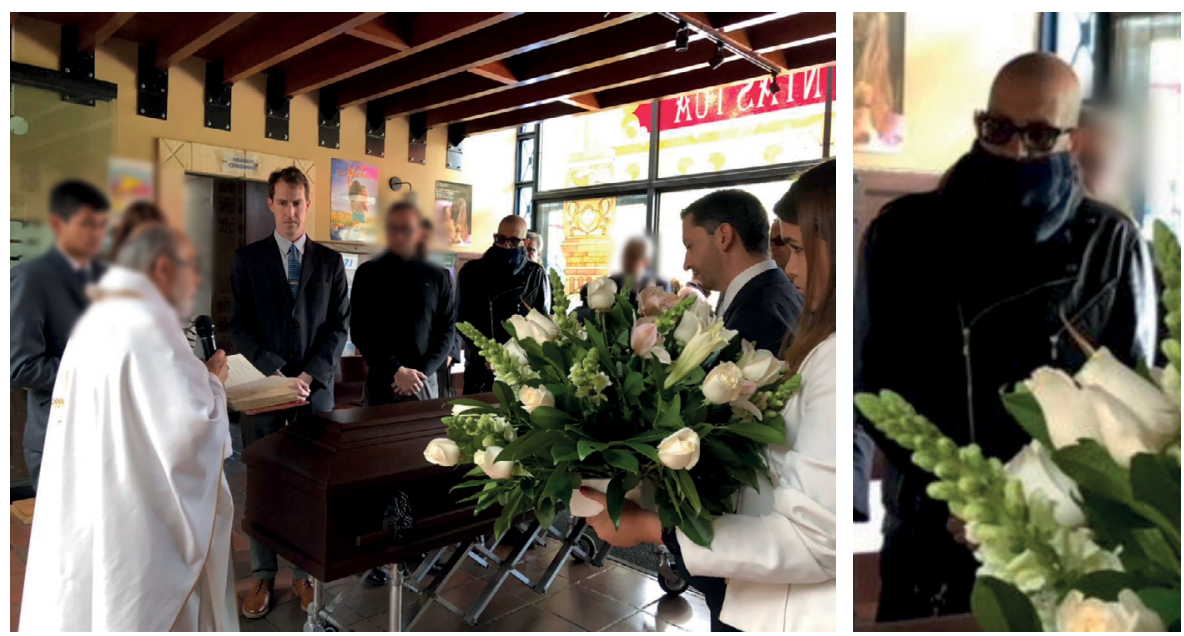

Source: Author's archive.

who probably rolled to the harder side of the rock, someone who liked to toe boundaries to see where they might be flexible, nudge them a bit while remaining on the acceptable side of respectability.

I said that it was obvious that Sergio was 'a special, passionate person,' but I think that more than that, he was fierce. 'Fierce' is the word I seem to return to when thinking about him. Not 'fierce' as in aggressive or meanquite the opposite of that-but 'fierce' in the depth of his passions.

A few images stick with me, mental snapshots of our time together.

The first is the two of us dressed up-he, freshly shaven and as formal as he got, with a wallet chain hanging out the back of his pants for good measure. The two of us a bit keyed up as we're about to go out to where he and my father and Lance Strate were to address those gathered at El Nogal to mark the launch of the new Ph.D. program for La Universidad de La Sabana - the whole reason my father and I were in Colombia (Image 2).

I have a picture, a selfie I took, to remind me of that moment, but I can feel it still (Image 3). 


\section{Image 2. Sergio and Eric in conversation (May 17, 2018).}

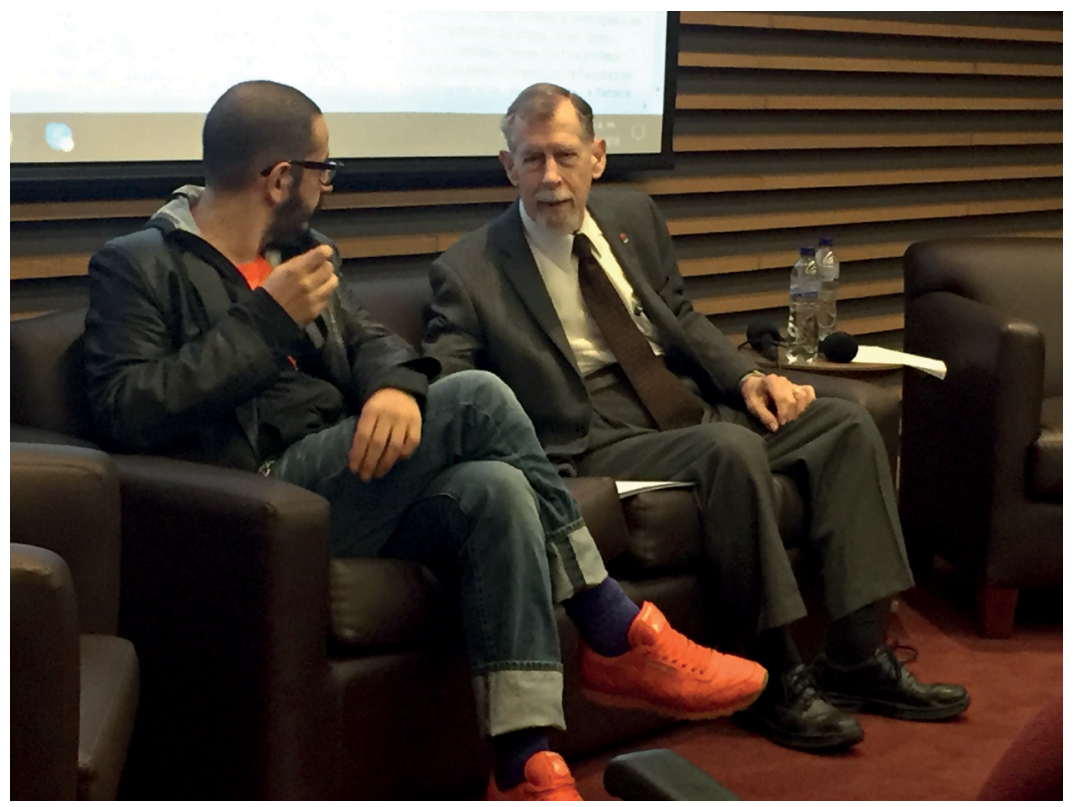

Source: Author's archive.

Image 3. Sergio and I, showtime (May 17, 2018).

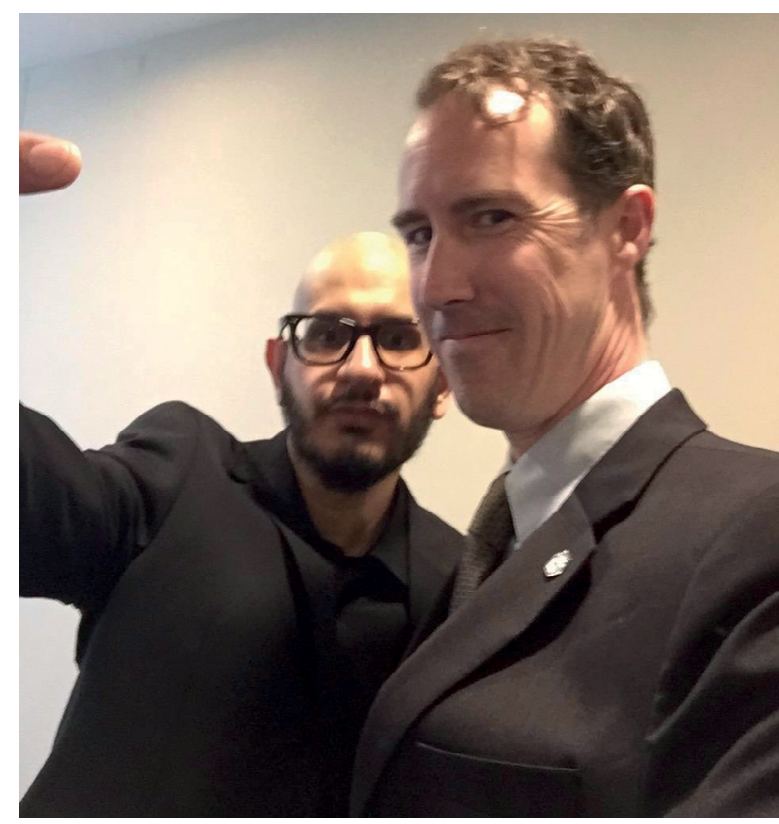

Source: Author's archive. 
I don't have a picture to remind me of this, but how could I ever forget: I am sitting, I had collapsed, on the floor outside the operating room where doctors and nurses were trying to bring my father back to life. Had they already pronounced him dead? I don't know. I look up, and here comes Sergio, running toward me with a look of the utmost concern on his face. Running, then pulling me into his arms.

I had found my father in our hotel room where we were supposed to meet for lunch before flying home that night. Maybe already past help, I clumsily performed CPR until an ambulance and paramedics showed up and took over. A mad rush, frustrated by traffic, to a nearby hospital. Being gently pushed into the hallway and collapsing on the floor, and then there's Sergio rushing toward me and holding me up.

Followed by others; but Sergio, first.

Much of the rest of that afternoon is a blur. It was quite a shock. I'm sure it wasn't long before others, more senior, arrived. Ana, Angela, Manuel.

I gained brothers and sisters that day. I was shown such kindness and love and care which I can never repay, but will always try to.

It was much later, dark when I was brought to my new hotel for the night.

I think I had something to eat in the hotel restaurant.

Not long after, a call from Sergio asking if I wanted to come to his place for some drinks, to hang out. God, yes.

Sergio and Edward showed up and brought me back to Sergio's place. They'd already started without me, but I gratefully accepted a beer. We spent a few hours there and it was a lot of fun - this is where Sergio and I bonded over music because as it turns out that not only were we both into punk rock, but both played guitar in bands. Sergio could not believe that 
I used to play in a punk band, so I proved it. We plugged in one of his guitars, and took turns playing and singing, looking up old stuff on the internet and playing that with a lot of laughs all around.

Next time, we said, next time I come back to Bogota, we'd play together on a stage.

By some minor or great miracles, I was home just a few days later with my father's ashes.

'Next time' should have been the following year, when I did return to Bogota, to give a speech in my father's honour. But most unfortunately Sergio wasn't well enough to see me.

We talked a bit online. He messaged to wish me a happy birthday. I heard he was better. Then I was blindsided with the news that he died.

Our friend Enrique broke my heart with the sad news in a WhatsApp message.

While I still feel a deep personal loss, and I know many others do as well, the deeper for having known him longer and more closely, I can't help but mourn the loss of what he could have accomplished.

My father died at age 76, at the peak of his career. His speech at El Nogal, 'Media Ecology in the $21^{\text {st }}$ Century' was a capstone.

Sergio Roncallo-Dow died at the beginning of his career. His speech at El Nogal, 'The South is the Message,' should have been the foundation for his life's work in building the Bogota School of Communication, which I have no doubt he was on his way to making major contributions toward.

Sergio pointed the way. He echoed my father's words from that night urging Colombians, 'the South,' to not merely follow in the footsteps of others, but to lead the way, following instead "the specificity of Latin America." 
Sergio's scholarship was substantial. And it should serve as a beacon to those who come after him. He had a passion that was beyond passion, it was fierce. Let it be an example to those who follow not to dim their passion for the sake of convention or decorum but to use it to fuel their pursuits, to study and ignite that fire in those they teach.

I've been told that my father is now a sort of patron saint, if that's the word, for the Doctoral Program in Communication at Universidad de La Sabana. Nothing could make me prouder, and it warms my heart. And I could think of no more appropriate person to join him in that position than Sergio, your own. With those two leading the way, you could go as far as you want to. My father told you that in starting something new to be bold, have courage. Sergio urged you to do it as Latin Americans, as Colombians-as yourselves.

Rest in peace, dear Sergio.

Andrew McLuhan

Bloomfield,

On 'Bloomsday'

June 16, 2020 